\title{
WHEN DOES AFFIRMATIVE ACTION IN FAVOUR OF CERTAIN EMPLOYEES BECOME UNFAIR DISCRIMINATION AGAINST OTHERS? ${ }^{1}$
}

\author{
DARCY DU TOIT \\ Professor of Law, Law Faculty, University of the Western Cape, South Africa
}

\begin{abstract}
Besides the oft-quoted passages in George v. Liberty Life [(1996) 17 II 571(IC)], which correctly stipulated that it was only the 'equal' enjoyment of rights that was the legitimate purpose of affirmative action policies, South African law is still developing clear principles that would underpin fair affirmative action policies. Or, in other words, the courts have not yet definitely ruled when it is not unfair to discriminate against employees who are not of the race targeted by affirmative action policies. ${ }^{2}$
\end{abstract}

\section{ABSTRACT}

The paper is concerned with the practical question of the circumstances under which measures which might otherwise have amounted to unfair discrimination will amount to affirmative action and will therefore be lawful. It addresses a number of conceptual issues, including whether affirmative should be understood as a limitation on the right to equality or an expression thereof; and the differing interpretations of 'discrimination' by Langa DP and Sachs $\mathrm{J}$ in City Council of Pretoria v Walker, in both cases preferring the latter approach. Reviewing the relevant case law up to May 2000, it considers whether the approach laid down by the High Court in Public Servants Association of SA v Minister of J ustice can survive the promulgation of the final Constitution and the Employment Equity Act. It also doubts whether the requirement of individual disadvantage in respect of affirmative action measures is (still) appropriate and suggests that underrepresentation of groups that suffered unfair discrimination is a preferable criterion.

\section{INTRODUCTION}

The title of this paper begs an important question. It is widely presumed that there is a contradiction between affirmative action and the right of employees not to suffer unfair discrimination. The right to implement affirmative action measures, from this standpoint, constitutes an exception to, and limitation upon, the right to equal treatment. Is this necessarily so? The question may seem moot at first sight. The difference between affirmative action and unfair discrimination, it may be argued, is a question of fact. Measures that amount to unfair discrimination in certain circumstances may in other circumstances amount to affirmative action. Whether they resort on one side or another of the dividing line will depend on the facts of each case. But this only begs a further question: how are those facts to be assessed? Which principle should be followed in deciding the nature of disputed measures? There is, it is submitted, a fundamental issue tied up in the process by which a court addresses the very question of fact. It is this: what is primary - the right to individual equality, or the broader social purpose of promoting 'substantive' equality between groups who have been subject to unequal treatment in the past? If the first approach is followed, affirmative action does indeed emerge as a limitation on the right to equality. It then follows from general principles of constitutional 
interpretation that it must be construed restrictively and, if so, certain presumptions must operate in favour of non-beneficiaries who challenge affirmative action measures.

If the second approach is followed, on the other hand, affirmative action emerges not as an exception to the right to equality but as a manifestation of it. From this standpoint, indeed, failure to implement affirmative measures may in certain circumstances amount to unfair discrimination against certain employees. IIf affirmative action is understood as the expression of a fundamental right rather than a limitation on it, the burden of proof will be relatively more favourable to beneficiaries of affirmative action - a fact that could alter the outcome of legal proceedings.

This paper sets out to give an overview of our developing labour jurisprudence in this area. It is indebted to earlier writings on the subject ${ }^{3}$ and, while it cannot improve on many of the conclusions already reached, will also deal with some of the more recent case law. It will furthermore consider the impact which the Employment Equity Act (EEA) ${ }^{4}$ may have on existing case law, which is based predominantly on a repealed provision ${ }^{5}$ of the Labour Relations Act (LRA). ${ }^{6}$ Finally, it will question certain of the opinions expressed in previous articles.

\section{DISCRIMINATION}

The starting point is the architecture of the affirmative action provisions in our labour law. Section 9(4) of the Constitution 7 prohibits any person from discriminating against another person on the grounds of race, gender, sex and fourteen other listed grounds. In terms of section 9(5) discrimination on any of these grounds is deemed to be unfair 'unless it is established that the discrimination is fair'. Section 6(1) of the EEA in similar terms prohibits discrimination 'against an employee in any employment policy or practice'. 8 'Employment policy or practice' is defined in comprehensive terms as including (but not limited to) every imaginable aspect of the employment relationship, including appointments and promotions. ${ }^{9}$

A critical question is when differential treatment of an employee amounts to 'discrimination' and, in that event, whether such discrimination is 'unfair'. Differentiation, after all, is inherent in employment - for example, in requiring particular qualifications for the performance of particular jobs. As a starting point, it is submitted, it should be accepted that 'discrimination' is not synonymous with 'differential treatment' but must incorporate some prejudicial or 'pejorative'10 element before it enters the purview of the law. Only if this has been established does 'differentiation' amount to 'discrimination' and does the question arise whether it is fair or unfair.11The application of this principle was illustrated by the Constitutional Court in City Council of Pretoria v. Walker 12 The differential treatment at issue was the policy that was adopted by the council officials ... to require the (white) residents of old Pretoria to comply with the legal tariff and to pay the charges made in terms of that tariff on pain of having their services suspended or legal action taken against them, whilst the (black) residents of Atteridgeville and Mamelodi were not held to the tariff, were called upon to pay only a flat rate which was lower than the tariff, and were not subjected to having their services suspended or legal action taken against them. ${ }^{13}$

The objective of the policy was a form of affirmative action in favour of township residents. In a closely-reasoned minority judgment Sachs J found that -the complainant [a white resident of 'old Pretoria'] has not made out a case of having suffered prima facie discrimination at all. In 
order to invoke the presumption of unfairness contained in section 8(4) [of the interim Constitution], ${ }^{14}$ some element of actual or potential prejudice must be immanent in the differentiation, otherwise there is no 'discrimination' to be evaluated, and the need to establish fairness or unfairness has no subject matter. ${ }^{15}$

The majority of the Court, however, found that the relatively favourable treatment accorded to black residents constituted indirect racial discrimination against white residents even though the latter suffered no derogation from their legal rights or historically accumulated privileges. But discrimination is not necessarily unfair. The Constitutional Court in Harksen v. Lane NO16established an approach that has been widely followed:

The determination whether differentiation amounts to unfair discrimination ... requires a two-stage analysis. Firstly, the question arises whether the differentiation amounts to 'discrimination' and, if it does, whether, secondly, it amounts to 'unfair discrimination'. It is well to keep these two stages of the inquiry separate. That there can be instances of discrimination which do not amount to unfair discrimination is evident from the fact that even in cases of discrimination on the grounds specified in $\mathrm{s} 8(2)^{17}$, which by virtue of s 8(4) are presumed to constitute unfair discrimination, it is possible to rebut the presumption and establish that the discrimination is not unfair. ${ }^{18}$

In City Council of Pretoria v. Walker 19 the Court went on to find that, while requiring black residents to pay only a flat rate was not unfair discrimination, the policy of taking legal action only against whites amounted to 'an invasion of their dignity' and was therefore unfair. This, it is submitted, does not overrule the requirement that discrimination must involve an element of prejudice but, rather, defines 'prejudice' as encompassing not only derogation from existing rights but also a denial of benefits or concessions which may, in certain circumstances, be unfair.

\section{THE SCOPE OF EMPLOYMENT EQUITY PLANS}

Section 6(2) of the EEA (following the Constitution) provides that [i]t is not unfair discrimination to -take affirmative action measures consistent with the purpose of this Act; or distinguish, exclude or prefer any person on the basis of an inherent equirement of a job. 20 Establishing affirmative action measures 'consistent with the purpose' of the EEA, thus, provides a complete defence to a claim of unfair discrimination. In cases where discrimination on grounds of race, gender or disability has been established it rebuts the presumption of unfairness adhering to such discrimination. ${ }^{21}$ Most obviously it refers to employment equity plans drawn up in accordance with Chapter III of the EEA. ${ }^{22}$ But the inquiry will not always be straightforward, and at least four areas can be distinguished where the statutory rule might be inapplicable or inconclusive. Firstly, Chapter III of the EEA has only been in force since 1 December 1999 and not all designated employers have drawn up employment equity plans. Affirmative action measures, on the other hand, have been implemented for some years by various employers in the public and private sectors. Disputes may therefore continue to be heard for some time in respect of affirmative action measures predating the implementation of employment equity plans (as in the cases discussed below).

Secondly, affirmative action measures by non-designated employers fall beyond the framework of statutory employment equity plans. While such measures may be taken in terms of affirmative action policies or plans, no presumption of fairness by reason of statutory compliance will be created and the status of any such measures, if challenged, will need to be 
established on a balance of probabilities. ${ }^{23}$ Thirdly, employment equity plans are by definition confined to the advancement of people from designated groups - i.e. black people, women and people with disabilities. ${ }^{24}$ Section 9(2) of the Constitution, however, creates a broader scope for affirmative action in favour of all or any 'persons, or categories of persons, disadvantaged by unfair discrimination'. Whether measures affirming non- designated groups (for example, religious minorities) amount to 'affirmative action measures' within the meaning of the Act would similarly need to be established without the assistance of any statutory presumption.

Finally, disputes may arise as to the validity of affirmative action measures contained within employment equity plans. 'Affirmative action measures' are measures designed to ensure that suitably qualified people from designated groups have equal employment opportunities and are equitably represented in all occupational categories and levels in the workforce of a designated employer. ${ }^{25}$

It is furthermore provided that affirmative action measures must be aimed inter alia at achieving the objectives listed in section 15(2) of the EEA. Affirmative action measures purporting to address any of these objectives, it would seem to follow, should reasonably be related to or capable of achieving such objectives while measures found to be unrelated or disproportionate to their purported objectives are likely to be found inconsistent with the purpose of the EEA. Where such measures are challenged, their lawfulness may have to be established by proving their proportionality and causal connection with their objectives on a balance of probabilities. ${ }^{26}$

\section{THE EARLY CASE LAW}

Following the seminal decision in George v. Liberty Life Association of Africa Ltd 27a series of further cases in which the validity of affirmative action measures was at issue have come before the courts, the Commission for Conciliation, Mediation and Arbitration (CCMA) and private arbitrators. ${ }^{28}$ The typical scenario has involved a white employee, aggrieved by the preferment of a black person, alleging unfair discrimination on the part of the employer and the latter raising the defence of affirmative action. In the George case, decided in terms of the interim Constitution, the Industrial Court upheld the validity of the employer's action, albeit subject to qualifications. ${ }^{29}$ In subsequent cases decided in terms of the LRA an important further requirement was added: affirmative action measures should not be isolated or haphazard actions on the part of the employer but should form part of a rational policy or plan of action (a) capable of achieving the objective of advancing persons from previously disadvantaged groups and (b) adequate for this purpose. 30 Measured against this criterion, purported affirmative action appointments were in certain cases found to have been 'irrational' or 'haphazard' and therefore failing to meet the test read into item 2(2)(b) of Schedule 7 to the LRA. ${ }^{31}$

The development of legal principle in this fertile new area of litigation has, however, proceeded somewhat haltingly. Several cases were disposed of on the basis of facts which brought the dispute into more established legal terrain, thus making it unnecessary to pronounce on the issue of affirmative action. ${ }^{32}$ For instance, in Department of Correctional Services v. Van Vuuren, 33the appointment of a black man instead of a more highly-recommended white woman was overturned by the Industrial Court (because the Department's affirmative action policy was not yet in force) but upheld by the Labour Appeal Court on the grounds that the appointment fell within the ordinary powers of the Public Service Commission. In Eskom v. Hiemstra NO, ${ }^{34}$ similarly, the dispute concerned a white woman passed over in favour of a black applicant. In this case the private arbitrator, while finding that the employer's affirmative action measures failed to meet the requirements of item 2(2)(b) of Schedule 7, ruled that the 
appointment of the black applicant should be upheld but that the grievant should be promoted to a similar rank. The employer's application for review failed on the grounds that the arbitrator had not exceeded his powers. The issue, in other words, was not whether the arbitrator's finding was correct but whether he had applied his mind and arrived at a rationally justifiable award. Though considered significant at the time, neither of the above- mentioned two cases broke new ground in defining the permissible nature and extent of affirmative action measures.

\section{THE IMPLICATIONS OF DEMOGRAPHIC CRITERIA}

An important principle, subsequently endorsed by the EEA, was asserted almost unnoticed in the private arbitration matter of Durban Metropolitan Council and SAMWU obo Lootzy. ${ }^{35}$ The dispute concerned the appointment of an African candidate in preference to a Coloured candidate who had been more highly rated in the selection procedure. The arbitrator upheld the appointment on the grounds that it was in conformity with the employer's affirmative action policy which justified measures to bring the demographic composition of its workforce in line with that of the metropolitan region. On the facts, African employees were underrepresented at the occupational level in question and the successful African applicant was suitably qualified to fill the position. These factors, together with the narrow difference in scores between the two candidates, persuaded the arbitrator that the employer's decision was fair.

The award thus asserted the principle that affirmative action in favour of persons from previously disadvantaged racial groups is not confined to seeking equitable representation as between black and white but also as between different categories of black employees. ${ }^{36}$ While the EEA does not state this expressly, it is implicit in the criteria for judging compliance with the EEA laid down in section 42(a). ${ }^{37}$

\section{THE MCINNES DECISION}

Against this background the Labour Court in the recent case of Antoinette Mclnnes v. Technikon Natal ${ }^{39}$ was again faced with a situation where a white woman had been passed over for appointment in favour of a black male. The applicant had been employed as a junior lecturer on annual contracts for two consecutive years. By the time her second contract was about to expire the temporary position which she filled was due to be made permanent and she had, in the judgment of the Court, a reasonable expectation of being offered this permanent position. 40 The normal appointments procedure was followed and the applicant was duly recommended for appointment by the selection committee.

Unexpectedly, however, the Academic Vice-Principal of the Technikon refused to confirm her appointment and instructed the committee to reconsider it in the light of the Technikon's affirmative action policy. The committee took the view - wrongly, it is submitted - that it had no further discretion and, while making clear its continued preference for Ms Mclnnes, recommended the appointment of the runner-up, a Mr Mpanza. Ms Mclnnes thereupon claimed unfair dismissal in terms of section 186(b) ${ }^{38}$ of the LRA or, in the alternative, unfair discrimination on grounds of race in terms of Schedule 7 to the LRA. The respondent pleaded that its conduct amounted to an affirmative action measure in terms of item 2(2)(b) of Schedule 7.

In the event, Penzhorn A J upheld the applicant's claim that the respondent's failure to appoint her to the position in question amounted to 'dismissal' ${ }^{39}$ and, since affirmative action cannot justify dismissal based on race, it followed that the dismissal was automatically unfair. The 
learned Acting Judge went on, however, to consider the alternative claim of unfair discrimination and ruled that, even if dismissal could not have been established, the respondent's defence of affirmative action would have failed. Unlike some earlier cases where employers' alleged affirmative action measures were found wanting, it was not the absence of a 'rational' affirmative action policy that threatened to invalidate the employer's decision in this case. The existence of an affirmative action policy in conformity with item 2(2)(b) was not in question.

Essentially, the Court found that the Technikon had breached its own policy and, while courts are reluctant to 'second guess' an employer's operational decisions, a different situation arises 'where it is found that the policy, read properly, was not applied at all'40

The critical part of the Court's reasoning appears from the following paragraphs:

The fact that Mr Mpanza was a member of the African community gave him a distinct advantage. This was an important factor having regard to the policy. But this factor had to be balanced against the need to provide the highest standard of tertiary service to its students. ${ }^{41}$ This could hardly have been achieved by appointing someone at the eleventh hour where the incumbent was the far better candidate and was able to continue with the work she was doing, particularly also where the appointee has no previous teaching experience.

The policy also does not regard race as the sole criteria [sic] where two persons are 'appointable'. It is far more subtle and sophisticated than that. An indicator that this is so is the requirement that reasons be given by the selection committee if the selected candidate is not from the targeted group. This would hardly be necessary where the person from the targeted group was to be appointed as long as he was 'appointable'. In fact, it seems to me that there would be no need for a selection committee at all if that were the sole criteria.

Two flaws in the course of action followed by the Technikon, it may be concluded, fatally undermined its defence of affirmative action. One was its preference for a candidate without lecturing experience when 'extensive lecturing experience' had been stated as a job requirement. By shortlisting Mpanza the Technikon might have precluded itself from raising his lack of experience as an objection to his appointment but could not, in so doing, detract from Mclnnes's right to fair labour practices nor from its own policy commitment to 'provide the highest standard of tertiary education' in order to 'redress the inequalities in students' educational and social backgrounds'. The factor of Mpanza's race in itself was insufficient to outweigh these considerations.

A second error crept in when, on being offered the appointment, Mpanza asked whether the salary was negotiable. Despite stating that it was not, the Technikon then proceeded to negotiate and, in order to obtain Mpanza's acceptance, offered him a salary higher than the advertised scale and higher, indeed, than that of the Head of Department. The Court found this action 'clearly in breach of the [affirmative action] policy'. The effect of the committee's revised decision, properly construed, was that Mpanza should be offered the position and, if he declined, it should be offered to Mclnnes. Mpanza did in effect decline the position but, rather than offering it to Mclnnes, the Technikon then made a new offer to Mpanza. Even if everything else had been as it should, this action would have rendered the Technikon's conduct unlawful. 45 The importance of the Mclnnes decision is that it underlines the role of the Court in scrutinising not only the content of an employer's professed affirmative action policy in order to determine whether it satisfies statutory requirements but also whether it is properly applied. Conduct not 
sanctioned by an affirmative action policy, even if the policy itself is valid, cannot provide a defence to a claim of unfair discrimination. 46

\section{THE AUF DER HEYDE DECISION}

On 5 May 2000 the Labour Court in Cape Town delivered judgment in the matter of Thomas auf der Heyde v. University of Cape Town. While affirmative action was a leitmotiv of the case, the judgment touched on it only in passing. Nevertheless an important element was added to our jurisprudence on the subject. The applicant, a white male, was one of three persons appointed as senior lecturers in the Department of Chemistry at UCT on three- year contracts with the possibility of extension for a further two years. During the initial three-year term his two colleagues were both appointed to permanent positions without such positions being advertised. The two colleagues were both black, one of them South African and the other non-South African. During the same period the applicant applied for an advertised position of lecturer in the same Department, which he was apparently qualified to fill, but was unsuccessful.

A material factor in the process was UCT's Equal Opportunity Employment Policy, making provision for affirmative action in the context of appointing 'the best staff' who 'over a period of time ... will make the greatest contribution to the work and the reputation of the University'. 48 One of the criteria for measuring the quality of appointments was the intrinsic value of diversity; another was the provision of 'adequate and acceptable role models . . . for a changing student body'. 49

The applicant claimed that the respondent's failure to appoint him to the advertised position, or alternatively to renew his contract for a further two years, amounted to an automatically unfair dismissal in that it resulted from the unfair application of its Equal Opportunity Employment Policy, alternatively of unfair discrimination on grounds of race and gender.50

As already noted, the Court followed the ruling in Dierks. v University of South Africa ${ }^{51}$ to the effect that reasonable expectation of permanent as opposed to temporary appointment cannot found a claim of dismissal. The Court ruled, however, that the applicant had a reasonable expectation that his contract would be renewed for a further two years ${ }^{52}$ and that failure to renew it therefore constituted dismissal. But the Court rejected the claim that such dismissal was racially motivated or in breach of UCT's affirmative action policy. The position for which the applicant had applied was a different one from the positions to which his two black colleagues had been appointed. And, since the contract of neither of the latter two persons was extended for a two-year period, there was no basis for finding that UCT's failure to extend the applicant's contract amounted to unfair discrimination. ${ }^{3}$

The Court accepted that the applicant's treatment was 'significantly different' from that of his two black colleagues ${ }^{54}$ but accepted also that this was justified by the respondent's affirmative action policy in terms of which the applicant did not 'qualify for special treatment'. ${ }^{55}$ The fact that affirmative action measures deliberately favour a particular target group or groups, in other words, does not in itself turn other persons into victims of unfair discrimination - but this, of course, is no more than a restatement of item 2(2)(b) of Schedule 7 to the LRA or section 6(2) of the EEA. New ground was broken, however, by the applicant's submission that a non-South African citizen cannot be a beneficiary of affirmative action. While no authority could be found in South African jurisprudence, the Court accepted that there was merit in the argument. ${ }^{56}$ The appointment of the applicant's non-South African colleague therefore fell beyond the ambit of 
affirmative action. But, since it was based not only on race but also on merit, it was justifiable in terms of UCT's employment policy. Given the absence of competition between the applicant and his colleague, moreover, any error on the part of UCT in applying its policy to the latter could not have prejudiced the applicant and was irrelevant to his claim.

The fact remained that, in the judgment of the Court, the applicant had been dismissed (in that his temporary contract had been terminated despite his reasonable expectation that it would be renewed). Argument on the implications was precluded by the concession made on behalf of UCT that, if it was found that dismissal had taken place, then it could only have been on grounds of operational requirements and, if so, it was procedurally unfair in that the procedure prescribed by the LRA had not been followed. ${ }^{57}$ An order of compensation in terms of the statutory formula was accordingly made. 58

\section{THE EMPLOYMENT EQUITY ACT: A TURNING POINT?}

Arguably, until comparatively recently a certain pattern was dis- cernable in the way that our labour courts interpreted affirmative action. ${ }^{59}$ Reviewing the case law prior to the Mclnnes and Auf der Heyde decisions, Rycroft suggests that contrary to the social purposes behind [affirmative action] policies, the adjudicative role can all too easily be a conservative one more attuned to the protection of individual rights than the promotion of broader social purposes. 60 This tendency cannot readily be divorced from the fact that most of the matters to come before the courts have involved white applicants attacking purported affirmative action measures. In this context, Rycroft notes, it appears that the requirements of a policy being narrowly tailored and imposing as tolerable a burden on discriminated groups as possible is emerging as the norm in our law. ${ }^{61}$ Notwithstanding some decisions to the contrary, it is difficult to disagree with the learned author's conclusion that [w] hat appears to be happening is that the intentions [now embodied in the EEA] are being diluted in the adjudicative process. ${ }^{62}$

In essence, the 'dilution' involved an elaboration of the concept of affirmative action. Following Public Servants Association of SA v. Minister of J ustice 63 it may be said that the two-stage test laid down in Harksen v. Lane $\mathrm{NO}^{64}$ acquired an additional stage if the defence of affirmative action was raised. The first stage was passed by establishing that 'discrimination' had taken place - for example, that a black person had been preferred over a white person on the basis of race. In cases involving affirmative action this fact would seldom be in dispute. In terms of the Constitution (though not the LRA) the onus then shifted to the employer to establish that such discrimination was fair. If the employer established that it was seeking to implement an affirmative action measure, however, this did not suffice to bring it within the ambit of item 2(2)(b) but gave rise to a third question: was the measure fair? An affirmative action measure, in effect, was only 'recognised' if it met the following criteria read into item $2(2)(b)$ :

it should be part of a coherent policy or plan with 'an articulated and specific design';65 it should be causally related and proportional to its objective, making as limited inroads as possible on the rights of other employees or workseekers; and the beneficiaries should personally have suffered disadvantage as a result of past unfair discrimination rather than merely belonging to a category of persons that suffered such discrimination. 66

Are these criteria consistent with the EEA and the new Constitution? The first and the third have certainly become questionable. It is doubtful whether the requirement that affirmative action measures must form part of an articulated plan can be maintained. On the one hand it is correct that an employer's mere assertion that a measure amounts to an affirmative action measure cannot be 
conclusive. Evidence should be led that it is indeed consistent with the 'purpose' of the EEA. The relevant 'purpose' of the EEA is to redress the disadvantages in employment suffered by designated groups [i.e. 'black people, women and people with disabilities'] in order to ensure their equitable representation in all occupational categories and levels in the workforce. ${ }^{67}$

This purpose, it is submitted, is served primarily and most obviously by employment equity plans drawn up and implemented by designated employers 68 in terms of Chapter III of the EEA. Measures forming part of such statutory plans should be regarded as being prima facie 'consistent with the purpose' of the EEA and therefore not unfair.

This, however, is a different proposition from the view that affirmative action measures can only be valid if they form part of such a plan. As noted already, the EEA requires affirmative action measures to be consistent with the purpose of 'redress[ing] the disadvantages in employment experienced by designated groups' in order to ensure their equitable representation in the workforce. The test, in other words, is whether a measure is causally linked to this objective - a relatively straightforward question that does not necessarily imply a formal strategy. The fact that a measure is (a) intended to contribute to the objective of equitable representation and (b) capable of doing so - for example, by reducing the underrepresentation of a particular designated group 69 - should be enough.

Thus, where a particular occupational grade is staffed exclusively by males and an employer appoints a suitably qualified female in preference to a more highly qualified male, it would surely be pedantic to challenge such appointment on the grounds that it does not form part of a pre-existing plan. Under-representation of persons from designated groups is a question of fact. Provided a measure can be shown to be reasonably related to the goal of reducing or eliminating such under-representation, it is submitted that it should be valid and that the existence of a policy or plan should be treated as evidence of the causal connection rather than a formal precondition. This interpretation is reinforced by section 9(2) of the Constitution which posits affirmative action not merely as a defence but as a proactive mechanism for promoting the achievement of equality. To this end it permits legislative and other measures designed to protect or advance persons, or categories of persons, disadvantaged by unfair discrimination. While every basic right may be limited to the extent permitted by section 36 of the Constitution, including the right to equality by means of affirmative action, the limitations previously read into the concept of affirmative action were not justified on this basis. The issue, instead, was the Court's interpretation of item 2(2)(b). It is doubtful whether the interpretation summarised above retains validity.

Similarly, the view that affirmative action measures can only be valid in respect of persons suffering individual disadvantage as a result of past unfair discrimination has become even more debatable. Rycroft explains this view:

[I]f race has not prevented education or training, the use of the term disadvantage is inappropriate. A consequence of this view is that any person seeking to utilise the EPPA70 must prove, on a balance of probabilities, that s/ he is [a] disadvantaged person because of her/ his race. The reason for this is that the EPPA does not assume that every black person or every woman or every physically disabled person is disadvantaged. ${ }^{71}$

The alleged victim of unfair racial discrimination, in other words, should prove the disadvantage which s/ he suffered as a result of being black. Even in the context of the LRA this view was problematical. Putting the victim to the proof, it is acknowledged, might be 'unnecessary' and 'wasteful' in that it 'exacerbates conflict and division'. ${ }^{72}$ But an even more important principle is at stake. The proposition that members of black communities should be deemed to have suffered no disadvantage unless they can prove the contrary appears fundamentally misplaced. South 
Africa's past policy of apartheid has been branded as a 'crime against humanity' and its devastating effect on black communities has been documented so amply as to require no additional proof. In respect of black persons, it is submitted, disadvantage should be presumed with rebuttal possible only on relatively narrow grounds - for example, in the case of a black South African born and educated outside South Africa who at no stage suffered disadvantage of the kind which the Constitution and the EEA have set out to undo.

It follows that, all things being equal, even relatively educated or prosperous black South Africans should be entitled to the benefit of affirmative action. The advantages that they enjoy were achieved despite the disadvantages imposed on them by apartheid. The presumption should remain, unless rebutted, that but for racial discrimination they are likely to have achieved even greater advantages. ${ }^{73}$ Similar presumptions should apply, mutatis mutandis, to women and people with disabilities in that they should not be required to prove facts which are not in any real dispute. The EEA has dealt with the issue by reversing the burden of proof in cases of unfair discrimination. Section 11 provides that [w] henever unfair discrimination is alleged in terms of this Act, the employer against whom the allegation is made must establish that it is fair. ${ }^{74}$ In respect of affirmative action it speaks of disadvantages 'experienced by designated groups'..$^{75}$ Group experience rather than individual experience, in other words, is indicated. While the reference is to present disadvantage rather than past disadvantage, it is submitted that, for the reasons outlined above, the effects of past disadvantage may be presumed to continue unless the contrary can be established.

A subjective approach to the concept of 'disadvantage' is problematical in other respects also. This was illustrated in the matter of Public Service Association - Gerhard Koorts v. Free State Provincial Administration ${ }^{76}$ where it was claimed that the applicant, a white woman, should also enjoy the benefits of affirmative action. The commissioner rejected this claim on the basis that white women did not suffer discrimination 'nearly to the same extent' as that experienced by blacks. The implication seems to be that claimants' (relative) entitlement to affirmative action needs to be established on the basis of proven deprivations suffered under apartheid. While this may be obvious in some cases, the task becomes more invidious where competing claims by members of different designated groups need to be adjudicated - for example, an Indian woman and an African man. It is submitted that the test of representivity is more closely compatible with the purpose of the EEA. 'Equitable representation' of persons from designated groups is integral to the concept of affirmative action ${ }^{77}$ and the degree to which persons of particular racial or gender groups are underrepresented in a particular occupational category or level within a workplace should determine the appropriateness of affirmative action in respect of applicants from the relevant groups. ${ }^{78}$ 
1. This paper incorporates parts of an earlier article by the author: du Toit, D. (2000) Affirmative action and unfair discrimination: Some fine dividing lines. Labour Law News \& CCMA Reports, 9, 1.

2. Arbitrator Whitcher in TWU obo Pretorius and Portnet (2000) 9 ARB 6.15.1.

3. For example, maternity leave. Few would dispute that, if this benefit is not extended to female employees, they will be disadvantaged (even more) vis-a-vis male employees

4. In particular, Rycroft, A. (1999) Obstacles to employment equity?: The role of judges and arbitrators in the interpretation and implementation of affirmative action policies. Industrial Law J ournal, 20, 1411.

5. Act 55 of 1998.

6. Item 2(1)(a) of Schedule 7 to the LRA.

7. Act 66 of 1995.

8. Act 108 of 1996.

9. The EEA adds 'HIV status' as a prohibited reason for discrimination. Subsequently, in Hoffmann v. South African Airways 2001 (1) SA 1(CC) (decided 28 September 2000) the Constitutional Court found discrimination on the basis of HIV status to be 'manifestly' unfair in terms of section 9 of the Constitution. A presumption of unfairness in respect of the listed grounds is not included in the EEA but the presumption created by section 9(5) of the Constitution should be read into the EEA. 'Harassment' on any of the listed grounds is expressly defined as a form of unfair discrimination (in section 6(3) of the EEA).

10. See Garbers, C (2000) Proof and evidence of employment discrimination under the Employment Equity Act 55 of 1998. South African Mercantile Law J ournal, 12, 144-145.

11. See also Prinsloo v. Van der Linde [1997] 6 BCLR 759 (CC); 19973 SA 1012 (CC) where it was held that 'discrimination' means 'treating persons differently in a way which impairs their fundamental dignity as human beings'.

12. Though inapplicable in an employment context, the definition of 'discrimination' in section 1(l)(viii) of the Promotion of Equality and Prevention of Unfair Discrimination Act 4 of 2000 explicitly incorporates an element of prejudice: "discrimination' means any act or omission ... . which directly or indirectly - imposes burdens, obligations or disadvantage on; or withholds benefits, opportunities or advantages from, any person on one or more of the prohibited grounds'.

13. 19982 SA 363 (CC); 1998(3) BCLR 257 (CC).

14. Per Langa DP at para 33.

15. 15 'Section 8(4) reads: "Prima facie proof of discrimination on any of the grounds specified in subsection (2) shall be presumed to be sufficient proof of unfair 
discrimination as contemplated in that subsection, until the contrary is established.' " (own emphasis) (footnote from the judgment).

16. At para 106.

17. 1998 1SA 300 (CC).

18. Of the Interim Constitution (Act 200 of 1993).

19. At paras $46 f f$. See also pll ff below. For further discussion see du Toit, D., Woolfrey, D., Murphy, J., Godfrey, S., Bosch, D. and Christie, S. (2000) Labour Relations Law 3 ed. pp. 432-444. Butterworths; Durban. See also Garbers (n 10) at 142-144.

20.See (n 13).

21. For discussion as to whether these two grounds constitute sole and exclusive defences to claims of unfair discrimination see du Toit et al (n 19) at 438.

22. It does not however override contractual obligations: see TWU obo Pretorius and Portnet (n 2) in which the employer's breach of an agreement to appoint a white male, though motivated by an affirmative action policy, was found to be 'both unfair and unlawful'.

23. See below for further information.

24. The more closely such policy or plan resembles a statutory employment equity plan, it may be inferred, the more likely it will be to withstand judicial scrutiny.

25. Section 1 of the EEA.

26. Section 15(1) of the EEA.

27. See, for example, Antoinette Mclnnes v. Technikon Natal (2000) 21 ILJ 1138 (LC), discussed below.

28.(1996) 17 ILJ 571(IC).

29. Reported cases include Van Zyl and Department of Labour (1998) 7 CCMA 5.3.1; Swanepoel v. Western Region District Council (1998) 9 BLLR 987 (SE); Durban Metropolitan Council (Parks Department) and SAMWU obo Lootzy (1998) 7 ARB 6.9.5; Metrorail and SALSTAFF obo Prinsloo \& others (1998) 7 ARB 6.9.6; MWU obo Van Coller and Eskom (1999) 9 BLLR 1089 (IMSSA); Eskom v. Hiemstra NO (1999) 20 ILJ 2362 (LC); Department of Correctional Services v. Van Vuuren (1999) 20 ILJ 2297 (LAC). See also the unreported awards cited in Rycroft (n 4) at fns 13 and 17-19 and the cases discussed below.

30. Qualifications included that the beneficiary of affirmative action must not only belong to a previously disadvantaged group but must have suffered personal disadvantage. Though criticised subsequently, this qualification might be construed as little more than a tautology. In casu the affirmative appointment of a coloured person was upheld on the 
basis that, due to his membership of a disadvantaged group, he had been educated in a deprived system and thereby personally disadvantaged. See further discussion below.

31. van Niekerk, A. (1997) Affirmative action - three cases, two views Contemporary Labour Law, 7, 9. The leading case is Public Servants Association of SA \& another v. Minister of J ustice \& others (1997) 5 BCLR 577 (T); (1997) 18 ILJ 241 (T), where the absence of such a policy or plan was held to be fatal to the defence of affirmative action. Grogan comments: '[I]n order to escape being branded unfair an affirmative appointment must be made to 'achieve the adequate protection and advancement of persons disadvantaged by unfair discrimination'. The word 'adequate' suggests that the benefits granted must be proportional to the goal of achieving equality. The granting of extravagant benefits which disproportionately enhance the positions of members of formerly disadvantaged groups at the expense of others would go beyond 'adequacy' in the sense intended by this provision'. See Grogan, J . (2000) Workplace Law 5 ed. p.204. J uta; Cape Town. The passage cited by Grogan is from item 2(2)(b) of Schedule 7 to the LRA, now replaced by section 6 of the EEA. The Public Servants Association judgment has been criticised as proceeding from a formal rather than a substantive concept of equality by van Niekerk. See also Rycroft (n 4) at $1420-1423$.

32. As in Public Servants Association v. Minister of J ustice (n 31) and MWU and Eskom (n 29).

33. Similarly, in Louw v. Golden Arrow Bus Services (Pty) Ltd (2000) 21 ILJ 188 (LC) the first claim of indirect pay discrimination based on race was disposed of on the grounds that the pay differential in question was commercially justifiable and therefore not discriminatory; and in Woolworths (Pty) Ltd v. Whitehead (2000) 6 BLLR 640 (LAC) a claim of unfair discrimination on grounds of pregnancy was dismissed by the Labour Appeal Court on the grounds that the applicant had failed to establish that pregnancy was the principal reason for her non- appointment. The contentious views expressed by Willis AJA on the nature and scope of permissible employer discrimination were for the most part obiter.

34. See (n 29).

35. See (n 29).

36. See (n 29).

37. See also Motala v. University of Natal (1995) 3 BCLR 374 (D). The same principle, it is submitted, applies in respect of gender representivity: using 'demographic profile' as a criterion (see $\mathrm{n} 35$ below) implies seeking an equitable balance between female and male employees within each racial group.

38. In terms of section 42(a)(i) regard must be paid to '[t]he extent to which suitably qualified people from and amongst the different designated groups are equitably represented within each occupational category and level in that employer's workforce in relation to the demographic profile of the national and regional economically active population. . .'

39. See (n 27). 
40.Inter alia she was told prior to being interviewed that 'provided she 'did not mess up' the position was hers' (at para 23). The Head of Department told her that she should apply merely 'as a matter of form'. These facts raise questions of a different nature about the fairness of the selection procedure.

41. Section 186(b) defines 'dismissal' as including the situation where 'an employee reasonably expected the employer to renew a fixed term contract of employment on the same or similar terms but the employer offered to renew it on less favourable terms, or did not renew it'.

42.In so doing, rejecting the finding of Oosthuizen AJ in Dierks v. University of South Africa (1999) 20 ILJ 1227 (LC) that section 186(b) is inapplicable to situations where an employee reasonably expected permanent employment as opposed to renewal of temporary employment. The reasoning was as follows: 'What section 186(b) clearly seeks to address is the situation where an employer fails to renew fixed term employment when there is a reasonable expectation that it would be renewed. It is the employer who creates this expectation and it is then this expectation, created by the employer, which now gives the employee the protection afforded by this section. If then the expectation which the employer creates is that the renewal is to be indefinite, then the section must be held to also cover that situation ... I must accordingly conclude that in arriving at this finding [that employees expecting permanent employment are excluded] His Lordship was clearly wrong.' (at para 20). The ruling in Dierks was followed by Jammy AJ in Auf der Heyde v. University of Cape Town (2000) 21 ILJ 1758 (LC) without reference to Mclnnes. It is respectfully submitted that the interpretation of Penzhom $\mathrm{AJ}$ is preferable. The decisions in Dierks and Auf der Heyde, whilst upholding the literal meaning of the sub-section, assert a hiatus in the protection extended to employees that is in conflict with the purpose of the LRA. In Dierks, indeed, the Court acknowledged that there is no logical basis for extending protection to employees on fixed-term contracts only if there is the prospect of a further fixed-term contract but withholding it once there is a prospect of permanent employment.

43. See (n 27) at para 43.

44. Similarly, in Public Servants Association v. Minister of J ustice (n 31) it was held that the respondent's constitutional and statutory duty to provide an 'efficient' service should not be compromised by its commitment to implement affirmative action measures. In Mclnnes the source of this countervailing duty was the respondent's own affirmative action policy.

45. It may be noted that, by the time the matter came to court, Mpanza had resigned and there was therefore no obvious barrier to the appointment of Mclnnes.

46. The EEA attempts to minimise litigation over issues such as those encountered in Mclnnes by stipulating that each employment equity plan should contain an internal dispute resolution procedure 4 to resolve any dispute about the interpretation or implementation of the plan' (section 20(2)(g)). Had this been done in the Mclnnes case it is possible that a less costly resolution might have been reached.

47. See (n 42).

48. Para 3 of the judgment. 
49. Ibid.

50. Ibid at para 11.

51. See (n 42).

52. Ibid at para 39 .

53. Ibid at para 59.

54. Ibid at para 56.

55. Ibid at paras 60-61.

56. Ibid at paras 70-72.

57. Ibid at paras 76-77.

58. Given the uncertainty that has surrounded the interpretation of section 194(1) of the LRA for some time, it should be noted for the sake of clarity that the Court followed the decision in Johnson \& Johnson (Pty) Ltd v. CWIU (1999) 20 ILJ 89 (LAC) and ordered compensation equivalent to twelve months' remuneration. The ruling in Whall $\mathrm{v}$. Brandadd Marketing (Pty) Ltd (1999) 20 ILJ 1314 (LC) to the effect that mitigation of damages should be taken into account was rejected - with respect, correctly so.

59. If the argument below is correct, it would mean that the judicial approach summarised here has been superseded.

60.See (n 4) at 1412.

61. Ibid at 1428.

62.Ibid at 1429 .

63. See (n 31).

64. See (n 7).

65. Rycroft (n 4) at 1428.

66. For more detailed discussion of the criteria asserted by the courts see Grogan (n 31) at 203-207.

67. Section 2(b). Although the EEA expressly links affirmative action measures to the objective of ensuring 'that suitably qualified people from designated groups . . . are equitably represented in all occupational categories and levels in the workforce of a designated employer '(section 15(1); own emphasis), the right to implement affirmative action measures applies to all employers. 'Designated employer' is defined in the (n 68) below. Since it would be incongruous to give 'affirmative action' a different meaning in the 
case of non-designated employers, it is submitted that the above definition applies to all employers.

68. Defined as employers with 50 or more employees, employers with total annual turnover in excess of that of a small business as defined in Schedule 4 to the EEA, municipalities, other organs of state excluding the National Defence Force and intelligence agencies, and employersappointed as designated employers in terms of collective agreements (see section 1, EEA).

69. Or, in terms of section 9 of the Constitution, other categories of persons disadvantaged by unfair discrimination.

70. The reference is to the Employment Practices Policy Agreement adopted by Durban City Council in 1992, containing an affirmative action policy.

71. See (n 4) at 1424-1425.

72. Ibid.

73. Indirect support for this submission appears from a grievance hearing referred to by Rycroft (ibid fn 69) in which an Indian grievant was deemed 'not sufficiently disadvantaged' to qualify for affirmative action but where the issue was nevertheless decided on the basis of 'the demographic representation of Indians in that job category'. The effects of societal discrimination on the individual applicant, in other words, could not be quantified but its effect on the composition of the workforce was manifest.

74. It would seem implicit that the onus of establishing the fact of discrimination remains with the applicant and that (in line with the Constitution) it is the unfairness thereof, rather than its commission, which is presumed. For a cautionary note see Garbers (n 10).

75. Section 2(b).

76. CCMA FS3915 21 May 1998 (unreported) as cited by Rycroft (n 4) at $1426 \mathrm{fn} 73$.

77. Section 15(1) of the EEA.

78. See also Motala v. University of Natal (n 37) at 6-7. 